\title{
BULK REFRIGERATION OF FRUITS AND VEGETABLES \\ PART II: COMPUTER ALGORITHM FOR HEAT LOADS \\ AND MOISTURE LOSS
}

\author{
by \\ Bryan R. Becker, Ph.D., P.E., Member ASHRAE \\ Associate Professor \\ Mechanical and Aerospace Engineering Department \\ Anil Misra, Ph.D., P.E. \\ Assistant Professor \\ Civil Engineering Department \\ Brian A. Fricke, Student Member ASHRAE \\ Research Assistant \\ Mechanical and Aerospace Engineering Department
}

\author{
University of Missouri-Kansas City \\ 5605 Troost Avenue \\ Kansas City, MO 64110-2823
}

27 November 1995 


\title{
Bulk Refrigeration of Fruits and Vegetables \\ Part II: Computer Algorithm for Heat Loads and Moisture Loss
}

\author{
Bryan R. Becker, Ph.D., P.E. (Member ASHRAE), Anil Misra, Ph.D., P.E. \\ and \\ Brian A. Fricke (Student Member ASHRAE) \\ University of Missouri-Kansas City \\ 5605 Troost Avenue, Kansas City, MO 64110-2823
}

\begin{abstract}
A computer algorithm was developed which estimates the latent and sensible heat loads due to the bulk refrigeration of fruits and vegetables. The algorithm also predicts the commodity moisture loss and temperature distribution which occurs during refrigeration. Part I focused upon the thermophysical properties of commodities and the flowfield parameters which govern the heat and mass transfer from fresh fruits and vegetables. This paper, Part II, discusses the modeling methodology utilized in the current computer algorithm and describes the development of the heat and mass transfer models. Part II also compares the results of the computer algorithm to experimental data taken from the literature, and, describes a parametric study which was performed with the algorithm. In addition, this paper also reviews existing numerical models for determining the heat and mass transfer in bulk loads of fruits and vegetables.
\end{abstract}

(Keywords: fruits; vegetables; refrigeration; heat transfer; mass transfer; transpiration; respiration; bulk load models; computer algorithms)

\section{INTRODUCTION}

This is the second part of a two-part paper that describes a computer algorithm which estimates the latent and sensible heat loads due to the bulk refrigeration of fruits and vegetables as well as the commodity moisture loss and temperature distribution during refrigeration. As discussed in Part I, this algorithm was developed as an aid to both the designer and the operator of refrigeration facilities for fruits and vegetables. Part I was devoted to the modeling treatment of those thermophysical properties of commodities and flowfield parameters which affect the heat and mass transfer from fruits and vegetables.

This paper (Part II) discusses the modeling methodology utilized in the current computer algorithm 
and describes the development of the mass and heat transfer models. Part II also compares the results of the computer algorithm to experimental data taken from the literature, and, describes a parametric study which was performed with the algorithm.

A review of the literature has revealed several existing models of the heat transfer in the bulk refrigeration of fruits and vegetables, some of these models also include mass transfer. Bakker-Arkema and Bickert (1966) developed a computational model of the cooling of fruits and vegetables in a deep bed. Their model does not take into account the effects of temperature gradient within a commodity, moisture loss, or respiration. The results of their model were compared with experimental data on sugar beets and it was found that the model predicted higher temperatures than those which actually occurred in the bulk load of sugar beets. Bakker-Arkema and Bickert attributed this difference to the model's lack of an evaporative cooling algorithm.

Baird and Gaffney (1976) developed a finite difference model to predict the heat transfer which occurs in bulk loads of fruits or vegetables. They assumed that no conduction heat transfer occurs between individual commodities, and that no mass transfer occurs between the commodities and the cooling air. The results of their numerical model were compared to experimental data for the forced cooling of oranges. The numerical and experimental data agreed well. It should be noted, however, that transpiration is not considered in this model and thus, it cannot be used to determine the latent heat load produced by fruits or vegetables stored in bulk.

A computer model was developed by Adre and Hellickson (1989) to predict the refrigeration load for apples and pears in cold storage during an entire storage season. Their model incorporates estimates of heat transmission through the building envelope, infiltration, equipment and commodity heat loads, including respiration. Adre and Hellickson report that their model compared favorably with data collected from a cold storage facility. However, it includes only an abbreviated heat transfer model and no mass 
transfer calculation.

A finite difference model for the cooling of swedes (rutabagas) in a deep bed was developed by Gan and Woods (1989). Their model includes the effects of respiration, moisture loss, and evaporative cooling, as well as a provision for the temperature gradient within the commodity. The transpiration rate is modeled using a transpiration coefficient consisting of two parts: a skin mass transfer coefficient and an air film mass transfer coefficient. A Sherwood correlation, used to determine the air film mass transfer coefficient, was experimentally determined for use with swedes. Comparison of their model results with experimental data on swedes yielded favorable agreement. However, their model was not generalized to include a variety of commodities.

Talbot et al. (1990) combined the Baird and Gaffney (1976) model with a porous media flow analysis to predict the temperature response of a load of oranges contained in a carton. The predicted temperature response was compared to experimental data collected on oranges to verify the applicability of the porous media flow model. It was found that the porous media flow model results were reasonable provided that variable porosity was used in the modeling of the orange cartons. However, this model does not consider moisture loss from the commodity.

MacKinnon and Bilanski (1992) developed a finite difference model of the heat and mass transfer from beds of thin leafy vegetables, such as lettuce. Heat from respiration was included in their model and mass transfer was modeled with a transpiration coefficient consisting of a skin mass transfer coefficient and an air film mass transfer coefficient. However, both the temperature gradient within the commodity, as well as the air flow rate dependence of the heat transfer coefficient were neglected. Their model results compared reasonably well with experimental data for leaf lettuce.

From this discussion, it can be seen that these existing bulk load heat and mass transfer models are not adequate to fulfill the needs of the designers and operators of bulk refrigeration facilities. Therefore, the 
current computer algorithm was developed to estimate the latent and sensible heat loads as well as the moisture loss and temperature distribution in the bulk refrigeration of fruits and vegetables. This current computer algorithm is capable of modeling a wide variety of commodities.

\section{MODELING METHODOLOGY}

The essence of the modeling methodology used in this investigation is described below in the context of the scenario depicted in Figure 1. This figure illustrates a one dimensional air flow pattern in which the air traverses the full length of the bulk load. Figure 2 shows detail of the computational model corresponding to this one dimensional air flow pattern within the bulk load of the commodity. In the computational model, the bulk load is represented as a porous medium composed of "commodity computational cells." The refrigerated air is modeled as "air parcels" which move through the "commodity computational cells." Figure 3 shows a flow chart of the time-stepping algorithm corresponding to this scenario.

Calculation commences with a specified initial temperature and humidity for the commodity bulk load and the air contained within it. As shown in Figure 2a, the time-stepping begins with the first refrigerated "air parcel" moving into the first "commodity computational cell." At the same time, each of the initial "air parcels" moves from its original cell into the adjacent cell, while the "air parcel" within the last "commodity computational cell" moves from the bulk load into the plenum of the refrigeration unit. Within each "commodity computational cell," the commodity surface water vapor pressure, $P_{s}$, and air stream water vapor pressure, $P_{a}$, are determined based upon the commodity surface temperature, $T_{s}$, the "air parcel" temperature, $T_{a}$, and the "air parcel's" mass fraction of water vapor, $m_{f}$. These vapor pressures are then used to calculate the commodity transpiration, $\dot{m}$, for the time-step, $\Delta t$. The mass fraction of water vapor in each "air parcel" is then updated to reflect the effects of transpiration. Subsequently, within each cell, the heat generation due to commodity respiration, $W$, the heat transfer from the commodity, $Q$, and the evaporative 
cooling due to transpiration are calculated for the time-step. Then, within each cell, the commodity temperature and the "air parcel" temperature are both updated to reflect the effects of the calculated respiration, heat transfer and evaporative cooling, thus completing the calculations for this time-step.

As shown in Figure 2b, the first "air parcel" moves to the second "commodity computational cell" and a newly refrigerated second "air parcel" moves into the first "commodity computational cell." This second "air parcel" encounters the previously updated commodity temperature in the first "commodity computational cell."

As the time-stepping continues, each "air parcel" traverses the entire commodity bulk load. The mass fraction of water vapor contained in each "air parcel," when it exits the bulk load, is used to calculate the latent heat load corresponding to that "air parcel," while its temperature is used to calculate its sensible heat load. As this algorithm time-steps towards a steady state, an estimate of the time histories of the latent and sensible heat loads, as well as commodity moisture loss and temperature distribution, are obtained.

\section{DESCRIPTION OF THE MASS AND HEAT TRANSFER MODELS}

The modeling of the mass and heat transfer, between the air and the bulk load of commodities within a "commodity computational cell," is achieved by formulating the mass and heat transfer with respect to a single commodity item, and then multiplying by the number of items resident within the "commodity computational cell." The number of commodity items resident within the "commodity computational cell," $n_{c}$, is determined by the following equation:

$$
\mathrm{n}_{\mathrm{c}}=\frac{\mathrm{W}_{\text {bulk }}}{\mathrm{W}_{\mathrm{c}} \bullet \mathrm{N}_{\text {cell }}}
$$

where $w_{\text {bulk }}$ is the mass of the bulk load, $w_{c}$ is the mass of a single commodity item and $N_{\text {cell }}$ is the number of "commodity computational cells" in the bulk load. 


\subsection{Mass Transfer Calculation}

As discussed in Section 2.1 of Part I, the moisture loss from a single commodity item is modeled as follows:

$$
\dot{\mathrm{m}}=\mathrm{k}_{\mathrm{t}}\left(\mathrm{P}_{\mathrm{s}}-\mathrm{P}_{\mathrm{a}}\right)
$$

where $P_{s}$ is the water vapor pressure at the surface of the commodity and $P_{a}$ is the water vapor pressure in the refrigerated air. Both $P_{s}$ and $P_{a}$ are evaluated at the previous time step by utilizing the relationships developed in Sections 3.1 through 3.3 of Part I. The transpiration coefficient, $k_{t}$, is given as:

$$
\mathrm{k}_{\mathrm{t}}=\frac{1}{\frac{1}{\mathrm{k}_{\mathrm{a}}}+\frac{1}{\mathrm{k}_{\mathrm{s}}}}
$$

where $k_{a}$ is the air film mass transfer coefficient and $k_{s}$ is the skin mass transfer coefficient as described in Sections 2.1.1 and 2.1.2 of Part I, respectively.

For one computational cell, the transpiration rate becomes:

$$
\dot{\mathrm{m}}_{\mathrm{t}}=\dot{\mathrm{m}} \mathrm{A}_{\mathrm{s}} \mathrm{n}_{\mathrm{c}}
$$

where $\dot{m}_{t}$ is the total transpiration rate in the computational cell, $\dot{m}$ is the transpiration rate per unit area of the commodity surface, $A_{s}$ is the surface area of a single commodity item, and $n_{c}$ is the number of commodities in the computational cell.

During the time step, $\Delta t$, the mass of water vapor in the air of the computational cell increases as follows:

$$
m_{H 2 O}^{1}=m_{H 2 O}^{0}+\dot{m}_{t} \Delta t
$$

where $m_{\mathrm{H} 2 \mathrm{O}}{ }^{l}$ is the updated mass of water vapor in the air, $m_{\mathrm{H} 2 \mathrm{O}}{ }^{0}$ is the mass of water vapor in the air from the previous time step, $\dot{m}_{t}$ is the transpiration rate and $\Delta t$ is the time step size. 
To find the mass of water vapor in the air from the previous time step, the mass fraction of the water vapor in the air from that time step must first be calculated. The mass fraction of water vapor in the air of the computational cell at the end of the previous time step, $m_{f}^{0}$, may be found as follows:

$$
\mathrm{m}_{\mathrm{f}}^{0}=\frac{\mathrm{w}^{0}}{1+\mathrm{w}^{0}}
$$

where $w^{0}$ is the humidity ratio of the air from the previous time step. The mass of water vapor in the air from the previous time step then becomes:

$$
\mathrm{m}_{\mathrm{H} 2 \mathrm{O}}^{0}=\mathrm{m}_{\mathrm{f}}^{0} \bullet \mathrm{m}_{\mathrm{a}}^{0}
$$

where $m_{a}{ }^{0}$ is the mass of the air in the computational cell at the end of the previous time step. This mass of air is given by:

$$
\mathrm{m}_{\mathrm{a}}^{0}=\rho_{\mathrm{a}}^{0} \mathrm{v}_{\mathrm{a}}
$$

where $\rho_{a}^{0}$ is the density of the air at the end of the previous time step and $v_{a}$ is the volume of the air in the computational cell.

The updated mass fraction of water vapor in the air of the computational cell, $m_{f}{ }^{1}$, then becomes:

$$
\mathrm{m}_{\mathrm{f}}^{1}=\frac{\mathrm{m}_{\mathrm{H} 2 \mathrm{O}}^{1}}{\mathrm{~m}_{\mathrm{a}}^{0}+\dot{\mathrm{m}}_{\mathrm{t}} \Delta \mathrm{t}}
$$

With the updated mass fraction of water vapor in the air, the new humidity ratio of the air, $w^{l}$, may be found:

$$
\mathrm{w}^{1}=\frac{\mathrm{m}_{\mathrm{f}}^{1}}{1-\mathrm{m}_{\mathrm{f}}^{1}}
$$

This completes the transpiration calculations for one computational cell for the current time step. 


\subsection{Heat Transfer Calculation}

In order to make the modeling of commodity heat transfer tractable, the commodities were assumed to be spherical in shape with uniform internal heat generation due to respiration. It was further assumed that the temperature within a commodity varied only in the radial direction. With these assumptions, the governing form of the transient heat equation is formally written as follows (Incropera and DeWitt, 1990):

$$
\frac{\mathrm{k}}{\mathrm{r}^{2}} \frac{\partial}{\partial \mathrm{r}}\left(\mathrm{r}^{2} \frac{\partial \mathrm{T}}{\partial \mathrm{r}}\right)+\rho \mathrm{W}=\rho \mathrm{c} \frac{\partial \mathrm{T}}{\partial \mathrm{t}}
$$

where $r$ denotes the radial direction within the commodity, $k$ is the commodity thermal conductivity, $T$ is the commodity temperature, $W$ is the respiratory heat generation of the commodity per unit mass, $\rho$ is the commodity density, $c$ is the commodity specific heat, and $t$ is time.

An explicit finite difference technique was applied to Equation (11) by dividing a commodity into $N$ spherical shells as shown in Figure 4. The resulting finite difference equation applicable to the center node is given as follows:

$$
\frac{\mathrm{k} \mathrm{A}_{1}}{\Delta \mathrm{r}}\left(\mathrm{T}_{2}^{0}-\mathrm{T}_{1}^{0}\right)+\rho \mathrm{V}_{1} \mathrm{~W}_{1}=\frac{\rho \mathrm{c}_{\mathrm{V}_{1}}\left(\mathrm{~T}_{1}^{1}-\mathrm{T}_{1}^{0}\right)}{\Delta \mathrm{t}}
$$

where $A_{l}$ is the area through which heat is transferred from the center node, $\Delta r$ is the distance between nodes, $T_{2}^{0}$ is the temperature of the neighbor node at the previous time step, $T_{1}{ }^{0}$ is the temperature of the center node at the previous time step, $v_{l}$ is the volume of the center node, $W_{l}$ is the heat generation per unit

mass due to respiration for the center node, $T_{l}{ }^{l}$ is the temperature of the center node at the current time step and $\Delta t$ is the time step.

For the interior nodes, the finite difference equation becomes:

$$
\frac{\mathrm{k}_{\mathrm{i}-1}\left(\mathrm{~T}_{\mathrm{i}-1}^{0}-\mathrm{T}_{\mathrm{i}}^{0}\right)}{\Delta \mathrm{r}}+\frac{\mathrm{kA}_{\mathrm{i}}\left(\mathrm{T}_{\mathrm{i}+1}^{0}-\mathrm{T}_{\mathrm{i}}^{0}\right)}{\Delta \mathrm{r}}+\rho_{\mathrm{V}_{\mathrm{i}} \mathrm{W}_{\mathrm{i}}}=\frac{\rho \mathrm{c}_{\mathrm{V}_{\mathrm{i}}}\left(\mathrm{T}_{\mathrm{i}}^{1}-\mathrm{T}_{\mathrm{i}}^{0}\right)}{\Delta \mathrm{t}}
$$


where $A_{i-1}$ is the area through which heat is transferred from the neighbor node, $\Delta r$ is the distance between nodes, $T_{i-1}{ }^{0}$ is the temperature of the neighbor node at the previous time step, $T_{i}^{0}$ is the temperature of the current node at the previous time step, $A_{i}$ is the area through which heat is transferred from the current node, $T_{i+1}{ }^{0}$ is the temperature of the neighbor node at the previous time step, $W_{i}$ is the heat generation per unit mass due to respiration for the current node, $v_{i}$ is the volume of the current node and $T_{i}^{l}$ is the temperature of the current node at the current time step.

At the surface of the commodity, convection heat transfer, radiation heat transfer, and evaporative cooling due to transpiration must be considered. Thus, the finite difference equation at the commodity surface becomes:

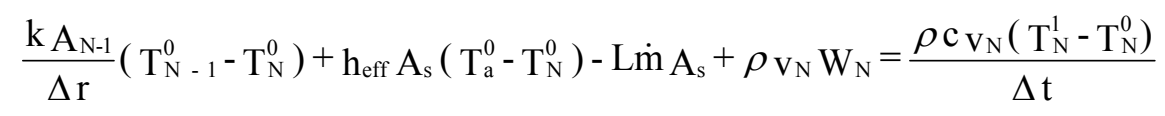

where $A_{N-1}$ is the area through which heat is transferred from the neighbor node, $\Delta r$ is the distance between nodes, $T_{N-1}{ }^{0}$ is the temperature of the neighbor node at the previous time step, $T_{N}{ }^{0}$ is the temperature of the surface node at the previous time step, $A_{s}$ is the surface area of a single commodity item, $T_{a}{ }^{0}$ is the air temperature at the previous time step, $L$ is the latent heat of vaporization for water, $\dot{m}$ is the transpiration rate per unit area of commodity surface, $v_{N}$ is the volume of the surface node and $T_{N}{ }^{l}$ is the temperature of the surface node at the current time step.

As discussed in Section 3.9 of Part I, the effective heat transfer coefficient, $h_{\text {eff }}$, includes both convection and radiation:

$$
\mathrm{h}_{\text {eff }}=\mathrm{h}_{\text {convection }}+\mathrm{h}_{\text {radiation }}
$$

The convection heat transfer coefficient, $h_{\text {convection }}$, is determined via a Nusselt-Reynolds-Prandtl correlation, Equation (35), given in Section 3.9.1 of Part I, while the radiation heat transfer coefficient, $h_{\text {radiation }}$, is given by Equation (39), derived in Section 3.9.2 of Part I. 
The formulation given by Equations (12) through (14) defines the temperature distribution within a single commodity item. However, Equation (14) requires knowledge of the temperature of the air parcel resident within the "commodity computational cell," $T_{a}{ }^{0}$. This air temperature is determined at each time step by performing a heat balance between the air parcel and that portion of the bulk load which is contained within the "commodity computational cell:"

$$
n_{c} h_{e f f} A_{s}\left(T_{a}^{0}-T_{N}^{0}\right)=m_{a}^{0} c_{p, a} \frac{\left(T_{a}^{1}-T_{a}^{0}\right)}{\Delta t}
$$

where $n_{c}$ is the number of commodity items resident within the "commodity computational cell," $m_{a}{ }^{0}$ is the mass of air in the computational cell and $c_{p, a}$ is the specific heat of air. This completes the formulation of the heat transfer model for one computational cell.

Since Equations (12) through (14) and (16) are explicit finite difference equations, they can be solved directly for the updated nodal temperatures. The heat transfer calculation begins at the commodity center node and proceeds outward to the air parcel. This completes the heat transfer calculation for one computational cell for the current time step.

\section{EXPERIMENTAL VERIFICATION OF THE COMPUTER ALGORITHM}

To verify the accuracy of the current computer algorithm, its calculated results were compared with experimental data obtained from the literature. Baird and Gaffney (1976) reported experimental data taken from bulk loads of oranges. They recorded commodity center and surface temperatures at the air exit of a bulk load for a period of two hours. The bulk load of oranges was $0.67 \mathrm{~m}(2.2 \mathrm{ft})$ deep and the commodities were initially at $32^{\circ} \mathrm{C}\left(90^{\circ} \mathrm{F}\right)$. The refrigerated air was at a temperature of $-1.1^{\circ} \mathrm{C}\left(30^{\circ} \mathrm{F}\right)$ and approached the bulk load with a velocity of $0.91 \mathrm{~m} / \mathrm{s}(3.0 \mathrm{ft} / \mathrm{s})$. Figure 5 shows Baird and Gaffney's experimental data along with the output from the current computer algorithm. Comparison of the model results with Baird and Gaffney's data on oranges shows that the current algorithm correctly predicts the trends of commodity 
temperatures with a maximum error of $1.4^{\circ} \mathrm{C}\left(2.5^{\circ} \mathrm{F}\right)$.

Gan and Woods (1989) gathered experimental data on swedes (rutabagas) during cooling in a thin bed. Air at $4.96^{\circ} \mathrm{C}\left(40.9^{\circ} \mathrm{F}\right), 83.71 \%$ relative humidity flowed at a velocity of $0.53 \mathrm{~m} / \mathrm{s}(1.7 \mathrm{ft} / \mathrm{s})$ through a bed of swedes which was initially at a temperature of $21.7^{\circ} \mathrm{C}\left(71.1^{\circ} \mathrm{F}\right)$. Commodity center temperature and moisture loss were recorded for a period of eight hours. Figure 6 shows the Gan and Woods temperature data along with the output from the current algorithm, while Figure 7 shows the Gan and Woods moisture loss data along with the output from the current algorithm. It is seen that the current algorithm correctly predicts commodity temperatures within $2.2^{\circ} \mathrm{C}\left(4.0^{\circ} \mathrm{F}\right)$ and moisture loss within $0.38 \%$.

Güemes et al. (1989) collected temperature data for the cooling of strawberries in a thin bed. Air with a velocity of $3.0 \mathrm{~m} / \mathrm{s}(9.8 \mathrm{ft} / \mathrm{s})$ and a temperature of $2.1^{\circ} \mathrm{C}\left(36^{\circ} \mathrm{F}\right)$ was used to cool the strawberries for a period of 16 minutes. As shown in Figure 8, the output from the current algorithm compares favorably with the data from Güemes et al. The maximum error between the computer algorithm and the experimental results was $1.9^{\circ} \mathrm{C}\left(3.4^{\circ} \mathrm{F}\right)$.

Brusewitz et al. (1992) conducted experiments to determine moisture loss from peaches during postharvest cooling. The post-harvest cooling was performed at $4{ }^{\circ} \mathrm{C}(39 \circ \mathrm{F}), 92 \%$ relative humidity in a chamber with 20 air changes per minute for a period of four days. Peaches were picked in the morning when the ambient temperature was $16^{\circ} \mathrm{C}\left(61^{\circ} \mathrm{F}\right)$. Experimental data from Brusewitz et al. shows that the peaches lost $2.5 \%$ of their weight due to moisture loss during the four day cooling period. The current computer algorithm predicted a weight loss of $2.53 \%$ at the end of the four day period, in good agreement with the experimental data. Figure 9 shows the results from the current computer algorithm as well as the experimental data.

\section{PARAMETRIC STUDIES UTILIZING THE CURRENT ALGORITHM}

A parametric study was performed to investigate the influence of various parameters on the 
calculated cooling time and moisture loss of bulk loads of commodities. This parametric study utilized a bulk load of apples with dimensions of $1 \mathrm{~m} \mathrm{X} 1 \mathrm{~m} \mathrm{X} \mathrm{2m} \mathrm{(3.3} \mathrm{ft} \mathrm{X} 3.3 \mathrm{ft} \mathrm{X} 6.6 \mathrm{ft})$ and a bulk weight of $800 \mathrm{~kg}$ $(1764 \mathrm{lb})$. The initial temperature of the load was taken to be $24^{\circ} \mathrm{C}\left(75^{\circ} \mathrm{F}\right)$. The dry bulb temperature of the refrigerated air was taken to be $1.67^{\circ} \mathrm{C}\left(35^{\circ} \mathrm{F}\right)$. The bulk load was divided into 5 cells and cooling was simulated for 12 hours. The effects of bulk weight, air flow rate and relative humidity on cooling time and moisture loss were investigated.

\subsection{Effect of Bulk Weight on Cooling Time}

Figure 10 shows the commodity center temperature versus time response at the air exit of the bulk load for bulk weights of $720 \mathrm{~kg}(1587 \mathrm{lb}), 800 \mathrm{~kg}(1764 \mathrm{lb})$ and $880 \mathrm{~kg}(1940 \mathrm{lb})$ with an air flow rate of $0.487 \mathrm{~m}^{3} / \mathrm{s}\left(17.2 \mathrm{ft}^{3} / \mathrm{s}\right)$ and a relative humidity of $89 \%$. It can be seen that a considerable difference in the time history of commodity center temperature exists between the three bulk loads. As is expected, an increase in bulk weight results in an increase in cooling time.

\subsection{Effect of Air Flow Rate on Cooling Time}

Figure 11 shows the commodity center temperature versus time response at the air exit of the bulk load for air flow rates of $0.440 \mathrm{~m}^{3} / \mathrm{s}\left(15.5 \mathrm{ft}^{3} / \mathrm{s}\right), 0.487 \mathrm{~m}^{3} / \mathrm{s}\left(17.2 \mathrm{ft}^{3} / \mathrm{s}\right)$ and $0.538 \mathrm{~m}^{3} / \mathrm{s}\left(19.0 \mathrm{ft}^{3} / \mathrm{s}\right)$ and a relative humidity of $89 \%$. As shown in Figure 11, cooling time decreases with increasing air flow rate.

\subsection{Effect of Air Flow Rate on Moisture Loss}

As shown in Figure 12, moisture loss decreases with increasing air flow rate. This is expected, since at higher air flow rates, the cooling time is reduced. A reduction in the cooling time decreases the vapor pressure deficit more quickly, thus retarding transpiration.

\subsection{Effect of Relative Humidity on Moisture Loss and Cooling Time}

To study the effects of the relative humidity of the incoming refrigerated air, the air wet bulb temperature was varied from $-3.3^{\circ} \mathrm{C}$ to $1.5^{\circ} \mathrm{C}\left(26^{\circ} \mathrm{F}\right.$ to $\left.34.7^{\circ} \mathrm{F}\right)$ while the air dry bulb temperature and flow 
rate were held constant at $1.67{ }^{\circ} \mathrm{C}\left(35^{\circ} \mathrm{F}\right)$ and $0.487 \mathrm{~m}^{3} / \mathrm{s}\left(17.2 \mathrm{ft}^{3} / \mathrm{s}\right)$, respectively. This results in a relative humidity range of $20 \%$ to $97 \%$. As shown in Figure 13, increased relative humidity results in decreased moisture loss. Such behavior is not unexpected. An increase in relative humidity causes a decrease in the vapor pressure deficit, thus decreasing transpiration. Relative humidity was found to have little or no noticeable effect upon the cooling time of the apples.

\subsection{Effect of Skin Mass Transfer Coefficient on Moisture Loss and Cooling Time}

For an air flow rate of $0.487 \mathrm{~m}^{3} / \mathrm{s}\left(17.2 \mathrm{ft}^{3} / \mathrm{s}\right)$ and a relative humidity of $89 \%$, the effect of the skin mass transfer coefficient, $k_{s}$, on moisture loss was investigated for the bulk load of apples. As discussed in Section 2.1.2 of Part I, the computer algorithm incorporates three values of skin mass transfer coefficient for each commodity: a low value, a mean value and a high value. As shown in Figure 14, a considerable difference in moisture loss is obtained between the three values of the skin mass transfer coefficient. An increase in the skin mass transfer coefficient results in an increase in transpiration. Skin mass transfer coefficient was found to have little or no noticeable effect upon the cooling time of apples.

\section{CONCLUSIONS}

These papers (Part I and II) have described the development and performance of a computer algorithm which estimates the latent and sensible heat loads as well as the moisture loss and temperature distribution in the bulk refrigeration of fruits and vegetables. This algorithm, which was developed as an aid to both the designer and the operator of refrigeration facilities, is capable of modeling a wide variety of commodities. Part I focused upon the thermophysical properties of commodities and the flowfield parameters which govern the heat and mass transfer from fresh fruits and vegetables.

This paper (Part II) described the modeling methodology which was devised for studying the mass and heat transfer processes within a bulk load of commodities. In the computational model, the bulk load is represented as a porous medium composed of "commodity computational cells" and the refrigerated air is 
modeled as "air parcels" which move through these "commodity computational cells." The modeling of the mass and heat transfer between the air and the bulk load is achieved by formulating the mass and heat transfer with respect to a single commodity item and then multiplying by the number of items resident within the "commodity computational cell."

A mass transfer model was developed to update the mass fraction of water vapor within each "commodity computational cell" at each time step based upon the transpiration model identified in Part I. An explicit finite difference formulation of the transient heat equation in spherical coordinates was derived which accounts for both radiation and convection heat transfer at the commodity surface. This formulation yields the temperature distribution within the commodities resident in each "commodity computational cell" at each time step. It also yields the temperature of the "air parcel" resident within each "commodity computational cell" at each time step.

To verify the accuracy of the current algorithm, its calculated results were compared with experimental data obtained from the literature. The results of the heat transfer model were compared to experimental temperature data for oranges, strawberries and swedes, while the results of the mass transfer model were compared to experimental moisture loss data for swedes and peaches. The results of these comparisons show good agreement between the numerical results and the experimental data for both temperature and moisture loss.

Utilizing the current computer algorithm, a parametric study was performed to investigate the influence of bulk weight, air flow rate, skin mass transfer coefficient and relative humidity upon the cooling time and moisture loss of a bulk load of apples. It was found that relative humidity and skin mass transfer coefficient had little effect on cooling time while bulk weight and air flow rate where of primary importance to cooling time. Moisture loss was found to vary appreciably with relative humidity, air flow rate and skin mass transfer coefficient while bulk weight had little effect. It is noteworthy that an increase in air flow rate 
results in a decrease in moisture loss. The increased air flow rate reduces the cooling time which quickly reduces the vapor pressure deficit, thus lowering the transpiration rate.

\section{NOMENCLATURE}

\begin{tabular}{|c|c|}
\hline$A_{i}$ & surface area of $i^{\text {th }}$ node \\
\hline$A_{s}$ & single commodity surface area \\
\hline$A_{1}$ & surface area of center node \\
\hline$c$ & specific heat of commodity \\
\hline$c_{p, a}$ & specific heat of air \\
\hline$h_{\text {convection }}$ & convection heat transfer coefficient \\
\hline$h_{\text {eff }}$ & effective heat transfer coefficient \\
\hline$h_{\text {radiation }}$ & radiation heat transfer coefficient \\
\hline$k$ & thermal conductivity of commodity \\
\hline$k_{a}$ & air film mass transfer coefficient (driving force: vapor pressure) \\
\hline$k_{s}$ & skin mass transfer coefficient (driving force: vapor pressure) \\
\hline$k_{t}$ & transpiration coefficient \\
\hline$L$ & latent heat of vaporization of water \\
\hline$m_{a}{ }^{0}$ & mass of air at time $t$ \\
\hline$m_{f}$ & mass fraction of water vapor in air \\
\hline$m_{f}^{0}$ & mass fraction of water vapor in air at time $t$ \\
\hline$m_{f}^{l}$ & mass fraction of water vapor in air at time $t+\Delta t$ \\
\hline$m_{H 2 O}{ }^{0}$ & mass of water vapor in air at time $t$ \\
\hline$m_{\mathrm{H} 2 \mathrm{O}}{ }^{l}$ & mass of water vapor in air at time $t+\Delta t$ \\
\hline$\dot{m}$ & transpiration rate per unit area of commodity surface \\
\hline$\dot{m}_{t}$ & transpiration rate in computational cell \\
\hline$n_{c}$ & number of commodities in computational cell \\
\hline$N_{\text {cell }}$ & number of computational cells \\
\hline$P_{a}$ & ambient water vapor pressure \\
\hline$P_{s}$ & water vapor pressure at evaporating surface of commodity \\
\hline$Q$ & heat transfer \\
\hline$r$ & commodity radius \\
\hline
\end{tabular}


$t$

$\Delta t$

$\rho$

$\rho_{a}{ }^{0}$

time

commodity temperature

dry bulb air temperature

air temperature at time $t$

air temperature at time $t+\Delta t$

temperature of $i^{\text {th }}$ node at time $t$

temperature of $\mathrm{i}^{\text {th }}$ node at time $t+\Delta t$

temperature of surface node at time $t$

temperature of surface node at time $t+\Delta t$

product surface temperature

temperature of center node at time $t$

temperature of center node at time $t+\Delta t$

volume of air in computational cell

volume of $i^{\text {th }}$ node

volume of surface node

volume of center node

humidity ratio at time $t$

humidity ratio at time $t+\Delta t$

mass of bulk load

mass of single commodity

rate of respiratory heat generation of commodity per unit mass of commodity

rate of respiratory heat generation of commodity per unit mass of commodity for node $\mathrm{i}$

rate of respiratory heat generation of commodity per unit mass of commodity for center node

length of node in radial direction

time step size

density of commodity

density of air at time $t$ 


\section{ACKNOWLEDGEMENT}

This project was sponsored by ASHRAE TC 11.5 and TC 10.9 under Project 777-RP. The support of ASHRAE is sincerely appreciated.

\section{REFERENCES}

Adre, N., and M.L. Hellickson. 1989. Simulation of the Transient Refrigeration Load in a Cold Storage for Apples and Pears. Transactions of the ASAE 32(3): 1038-1048.

Baird, C.D., and J.J. Gaffney. 1976. A Numerical Procedure for Calculating Heat Transfer in Bulk Loads of Fruits or Vegetables. ASHRAE Transactions 82(2): 525-540.

Bakker-Arkema, F.W., and W.G. Bickert. 1966. A Deep-Bed Computational Cooling Procedure for Biological Products. Transactions of the ASAE 9(6): 834-836, 845.

Brusewitz, G.H., X. Zhang, and M.W. Smith. 1992. Picking Time and Postharvest Cooling Effects on Peach Weight Loss, Impact Parameters, and Bruising. Applied Engineering in Agriculture 8(1): 84-90.

Gan, G., and J.L. Woods. 1989. A Deep Bed Simulation of Vegetable Cooling. In Agricultural Engineering, ed. V.A. Dodd and P.M. Grace, pp. 2301-2308. Rotterdam: A.A. Balkema.

Incropera, F.P., and D.P. DeWitt. 1990. Fundamentals of Heat and Mass Transfer. New York: John Wiley and Sons.

MacKinnon, I.R., and W.K. Bilanski. 1992. Heat and Mass Transfer Characteristics of Fruits and Vegetables Prior to Shipment. SAE Technical Paper 92 1620. Warrendale, PA: SAE.

Talbot, M.T., C.C. Oliver, and J.J. Gaffney. 1990. Pressure and Velocity Distribution for Air Flow Through Fruits Packed in Shipping Containers Using Porous Media Flow Analysis. ASHRAE Transactions 96(1): 406-417. 


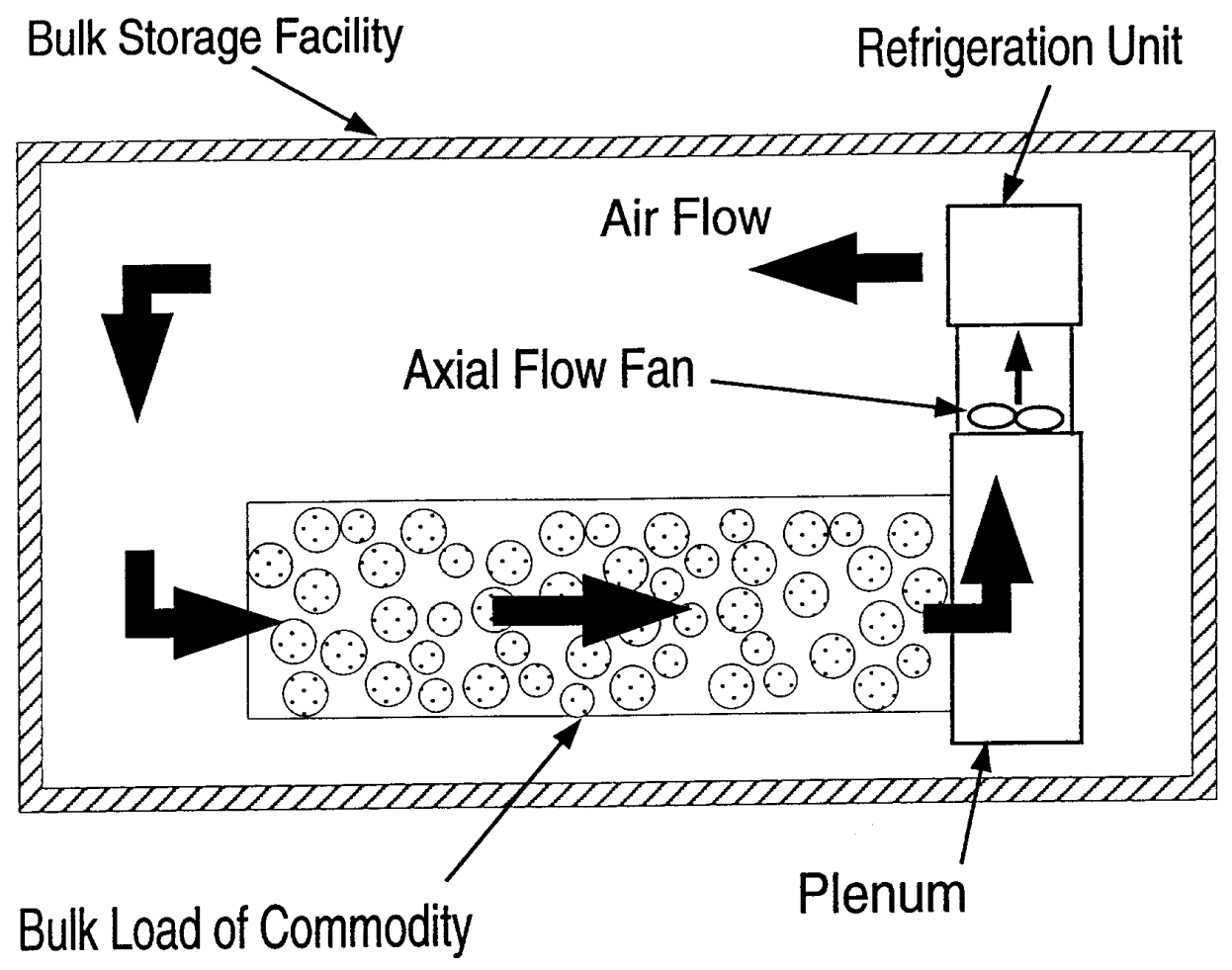

Figure 1. Refrigerated bulk storage of fruits and vegetables. 


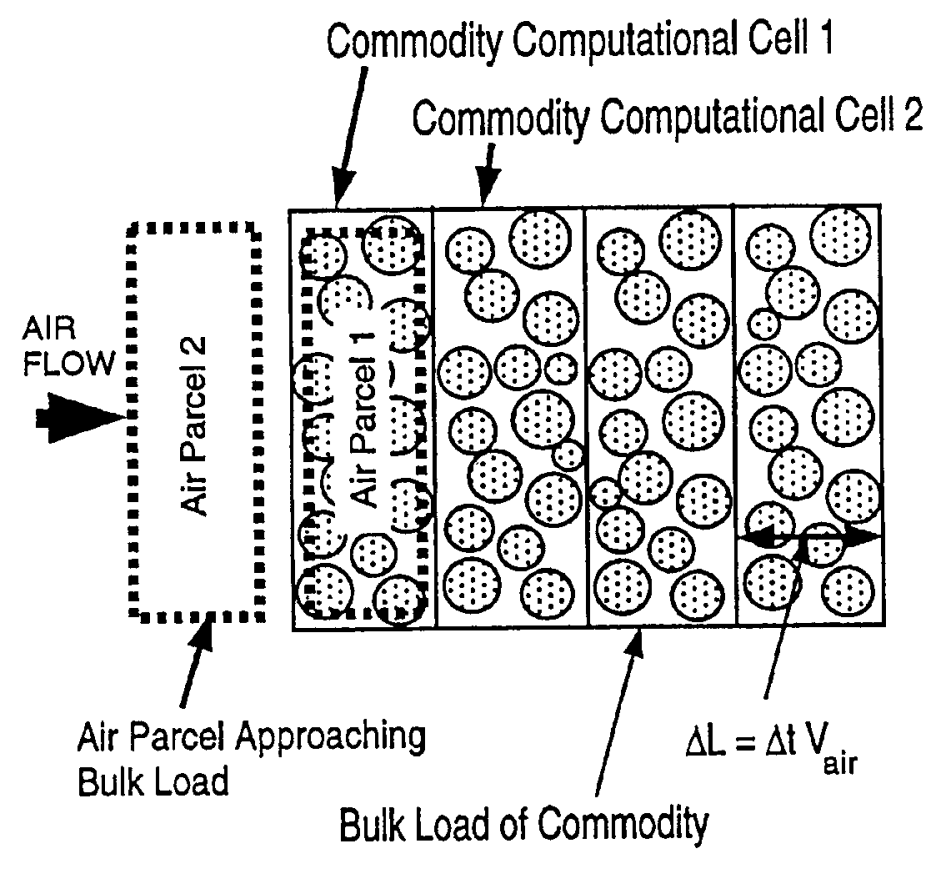

(a) Time $t$

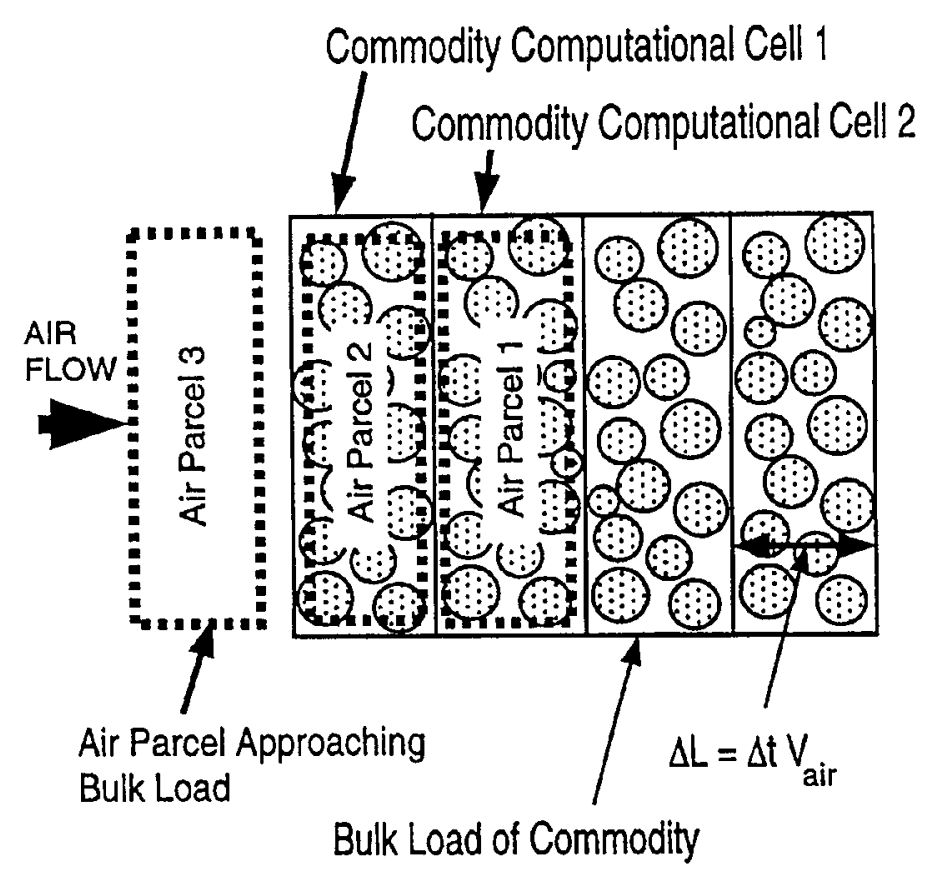

(b) Time $t+\Delta t$

Figure 2. Computational model of refrigerated air flow through bulk load of commodity. 


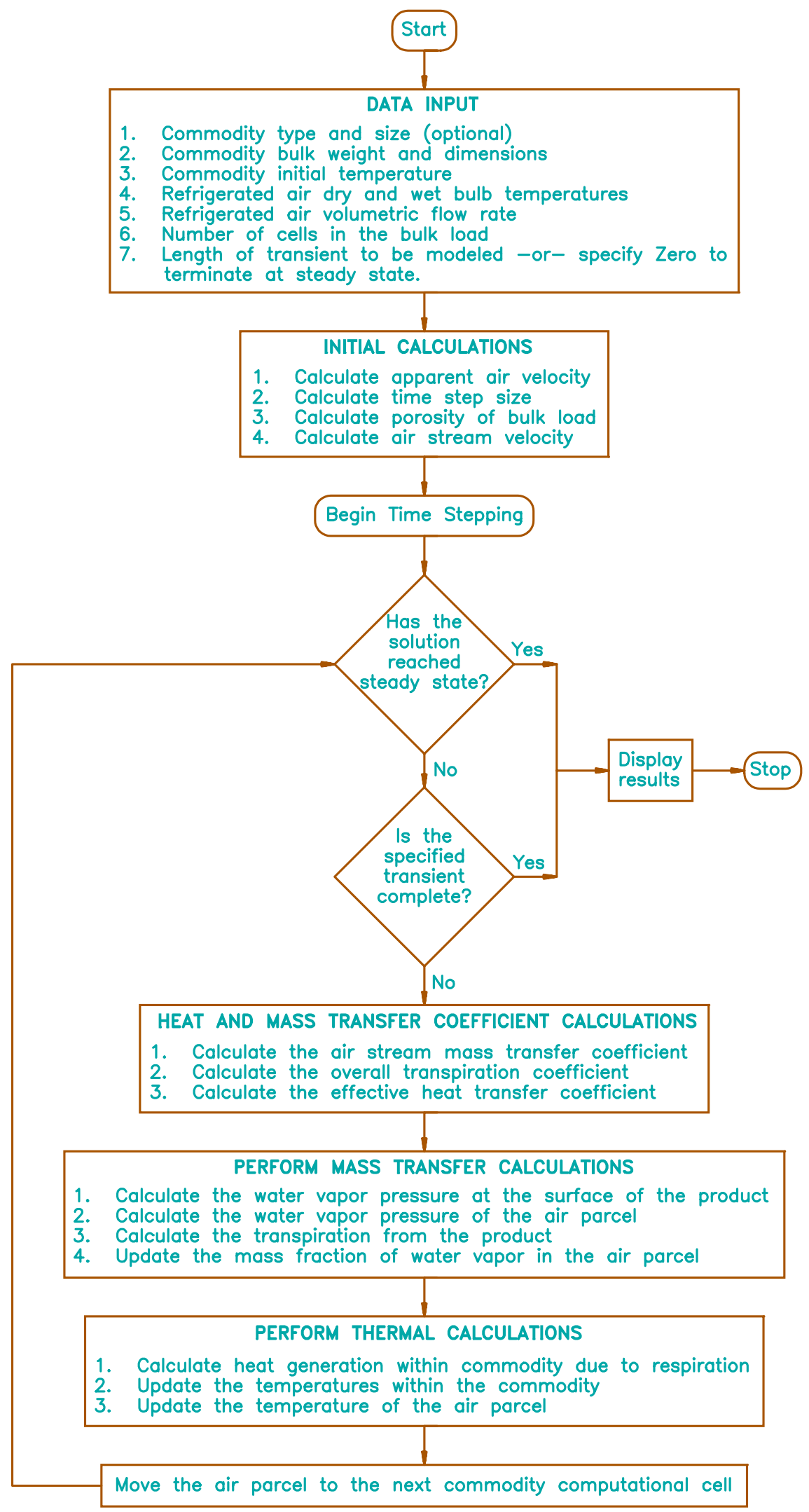

Figure 3. Flow chart of time-stepping algorithm. 


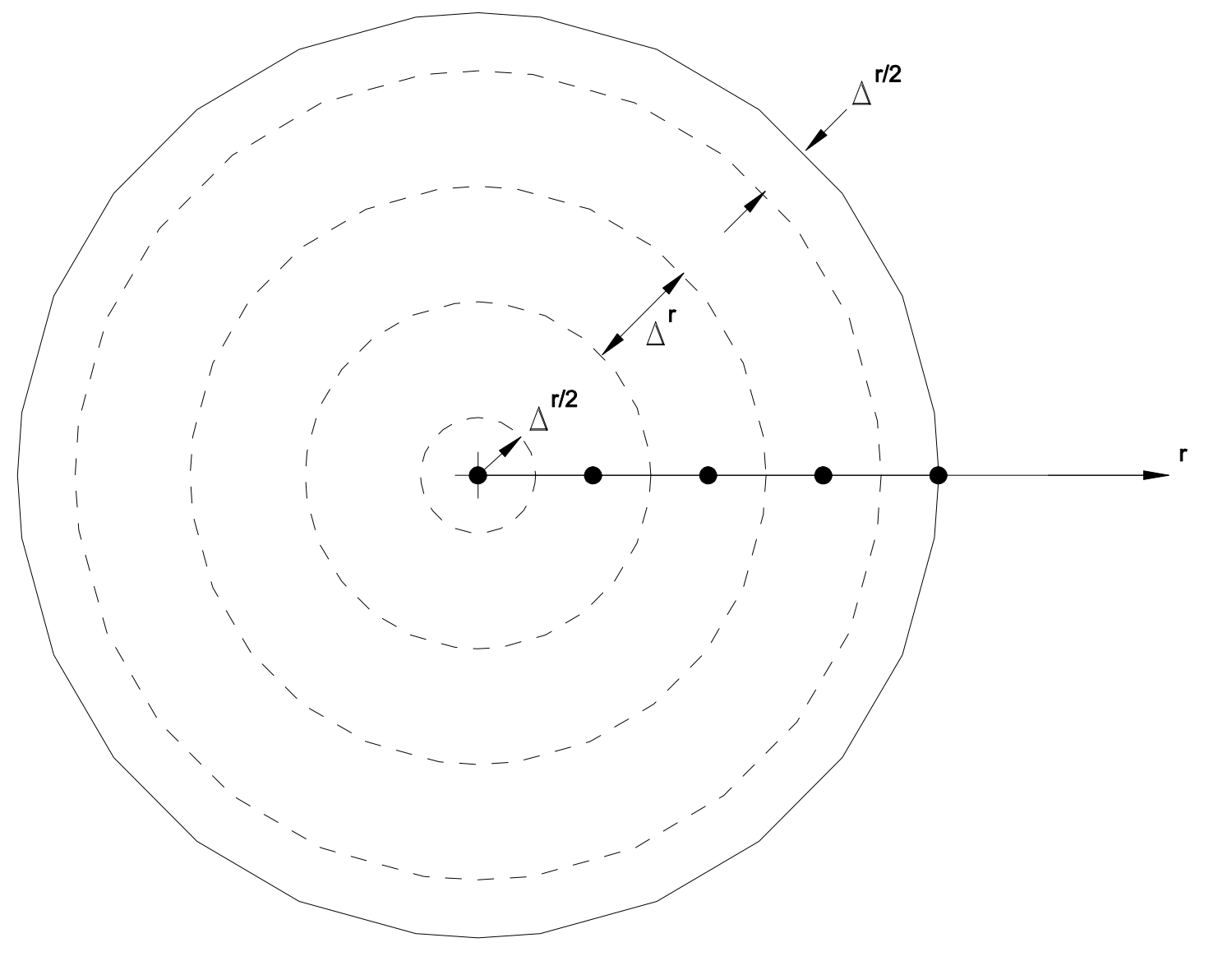

Figure 4. Commodity grid. 

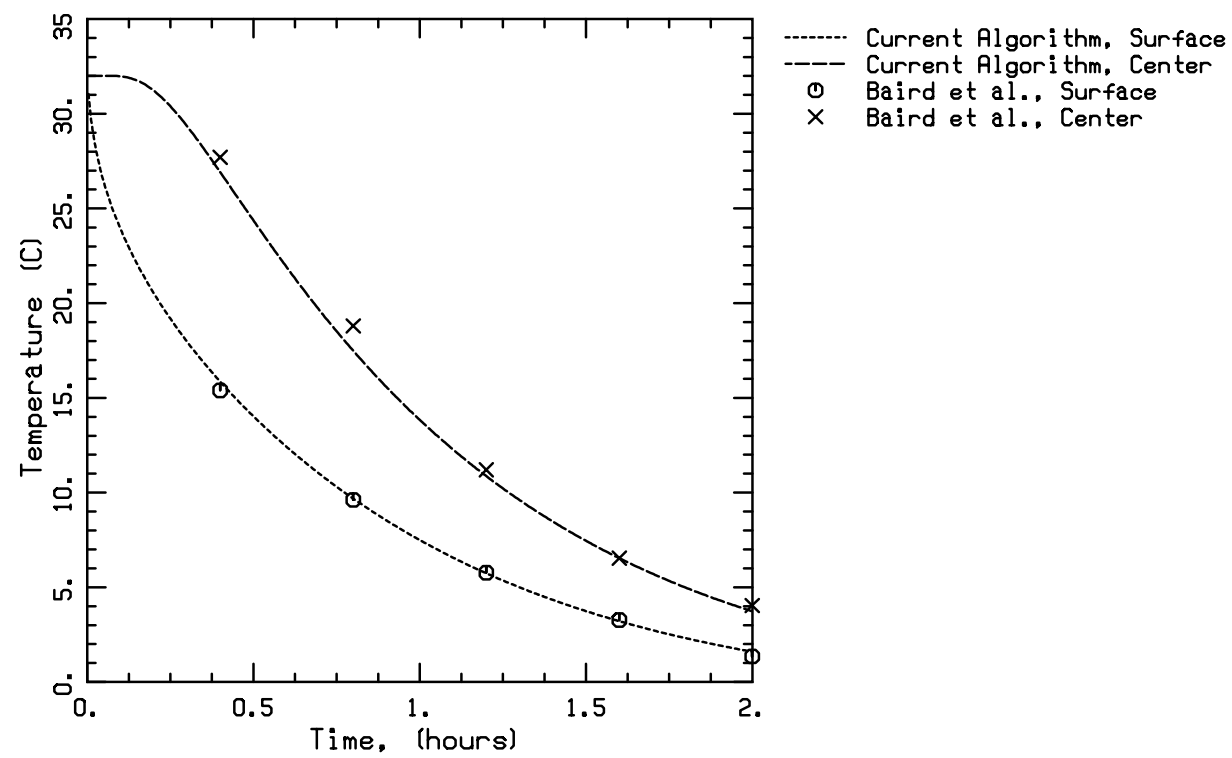

Figure 5. Current numerical results and experimental temperature data for forced air cooling of oranges from Baird and Gaffney (1976). The approaching air temperature and velocity were $-1.1^{\circ} \mathrm{C}$ and $0.91 \mathrm{~m} / \mathrm{s}$, respectively.
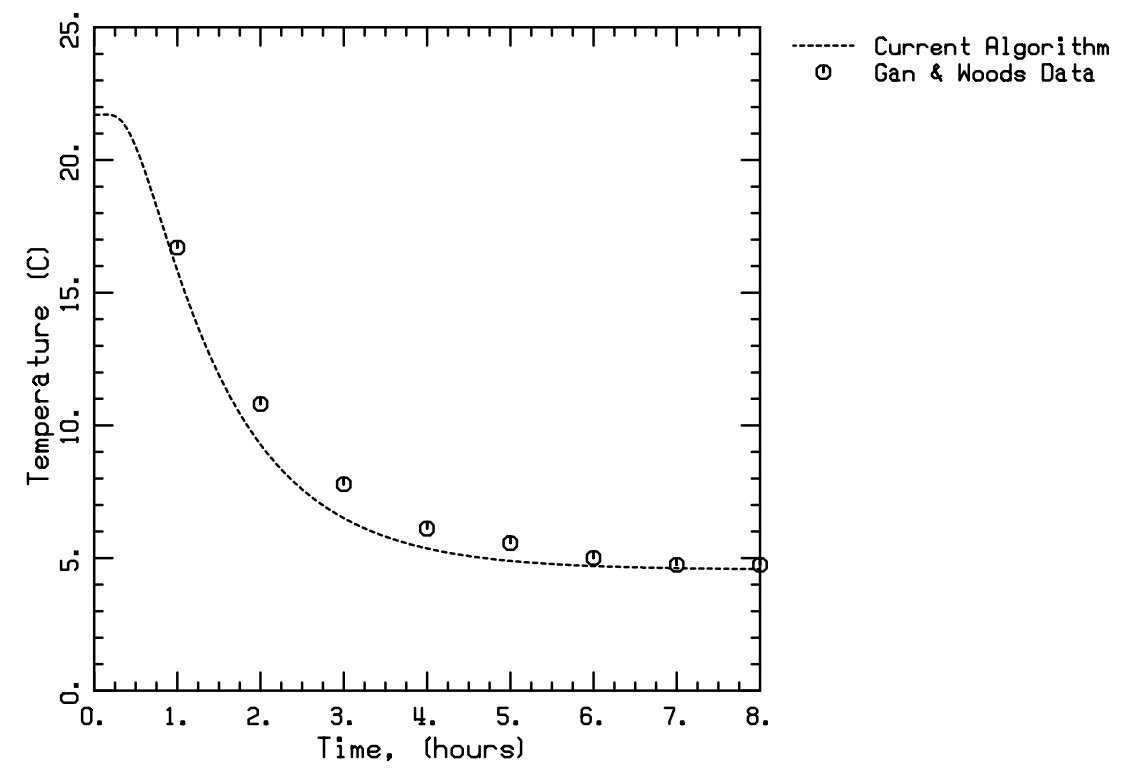

Figure 6. Current numerical results and experimental temperature data for forced air cooling of swedes from Gan and Woods (1989). The approaching air temperature, relative humidity and velocity were $4.96^{\circ} \mathrm{C}, 83.71 \%$, and $0.53 \mathrm{~m} / \mathrm{s}$, respectively. 


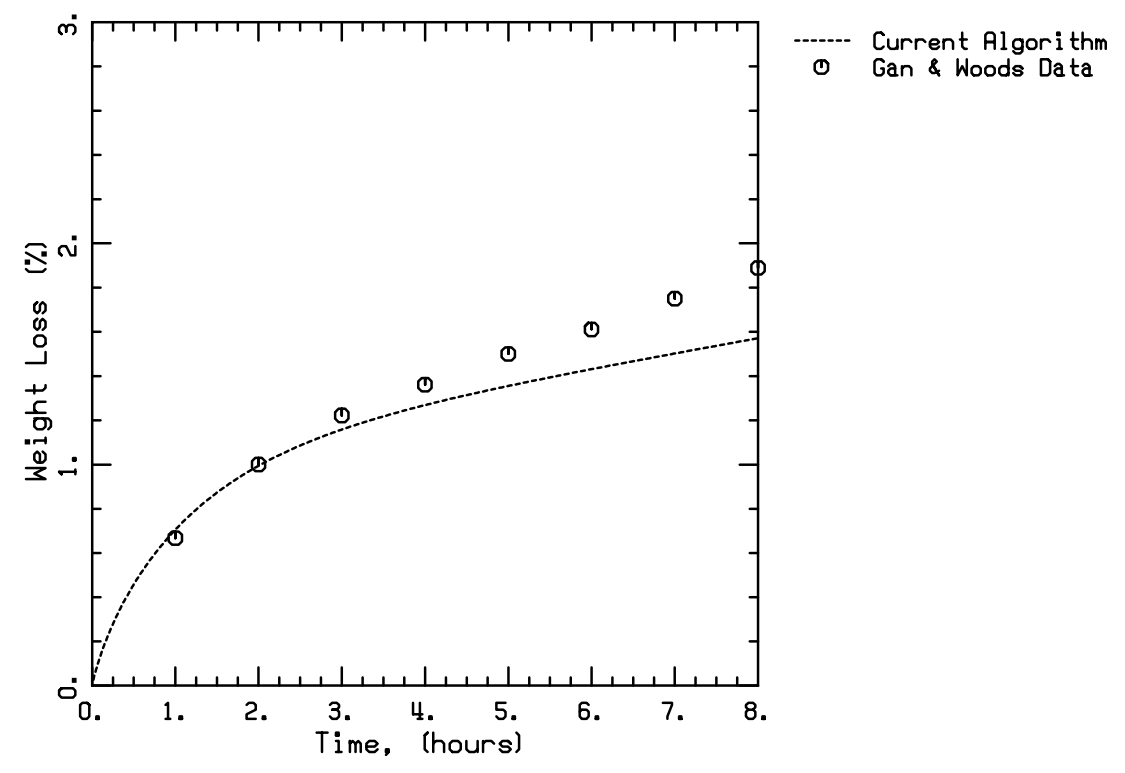

Figure 7. Current numerical results and experimental moisture loss data for forced air cooling of swedes from Gan and Woods (1989). The approaching air temperature, relative humidity and velocity were $4.96^{\circ} \mathrm{C}, 83.71 \%$, and $0.53 \mathrm{~m} / \mathrm{s}$, respectively.

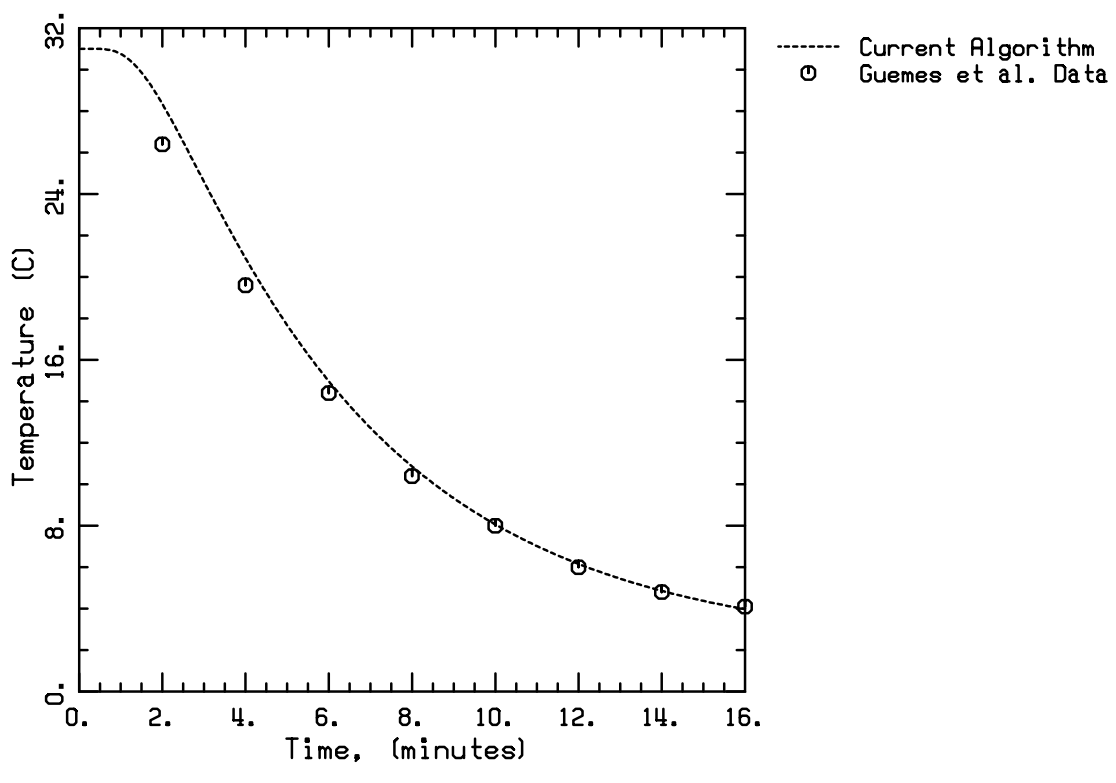

Figure 8. Current numerical results and experimental temperature data for forced air cooling of strawberries from Güemes et al. (1989). The approaching air temperature and velocity were $2.1^{\circ} \mathrm{C}$ and $3.0 \mathrm{~m} / \mathrm{s}$, respectively. 


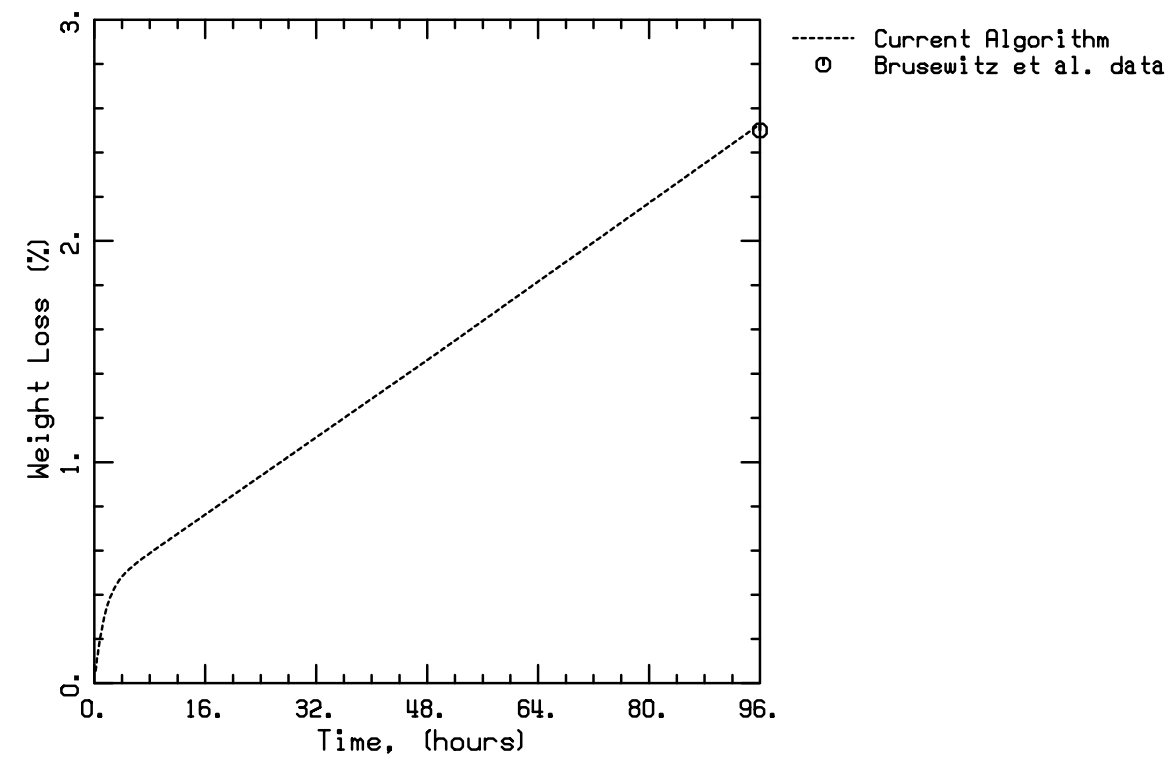

Figure 9. Current numerical results and experimental moisture loss data for post harvest cooling of peaches from Brusewitz et al. (1992). Cooling was performed at $4.0^{\circ} \mathrm{C}, 92 \%$ relative humidity with 20 air changes per minute.
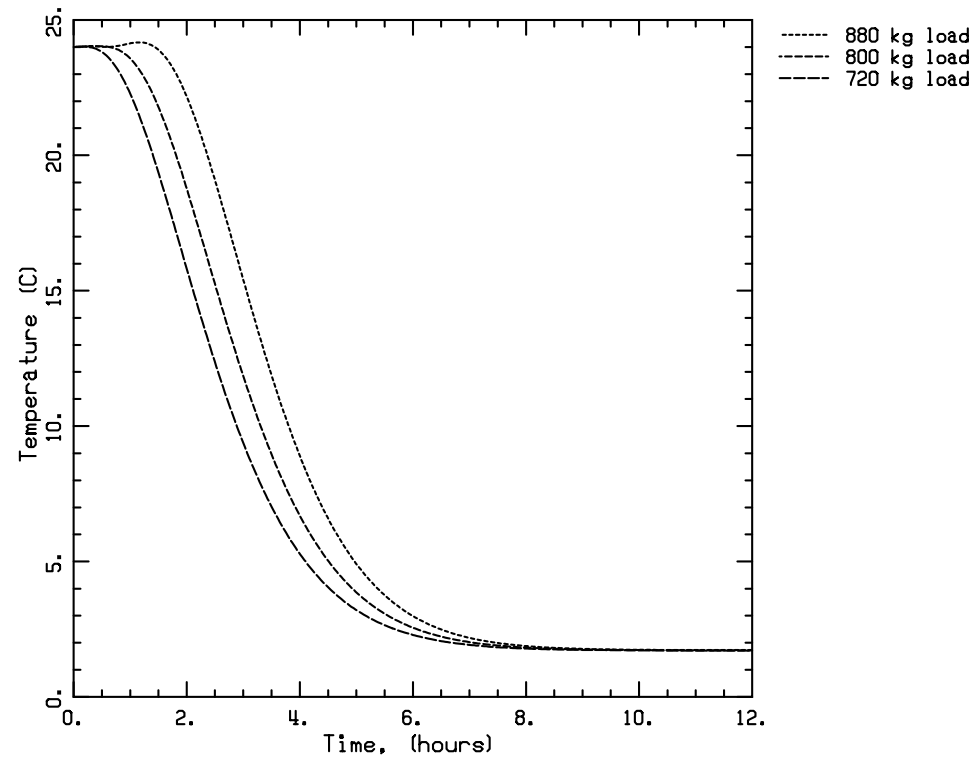

Figure 10. Effect of bulk weight on the forced air cooling time of apples located at the air exit of the bulk load. The approaching air temperature, humidity and flow rate were $1.67{ }^{\circ} \mathrm{C}, 89 \%$, and $0.487 \mathrm{~m}^{3} / \mathrm{s}$, respectively. 


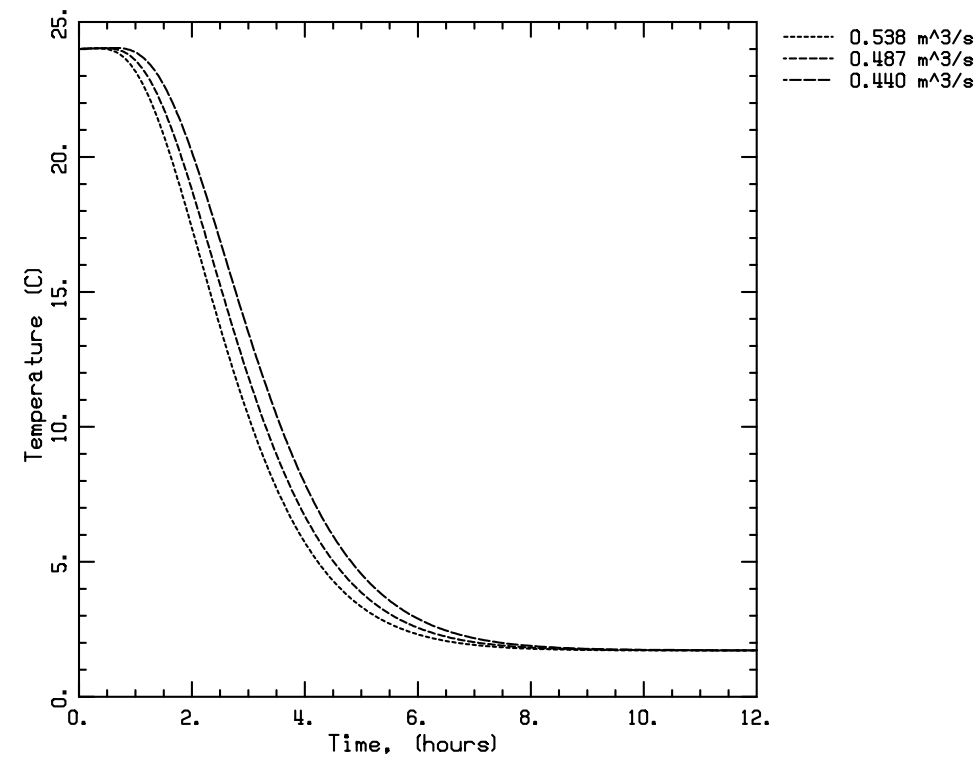

Figure 11. Effect of air flow rate on the forced air cooling time of apples located at the air exit of the bulk load. The approaching air temperature and humidity were $1.67{ }^{\circ} \mathrm{C}$ and $89 \%$, respectively.

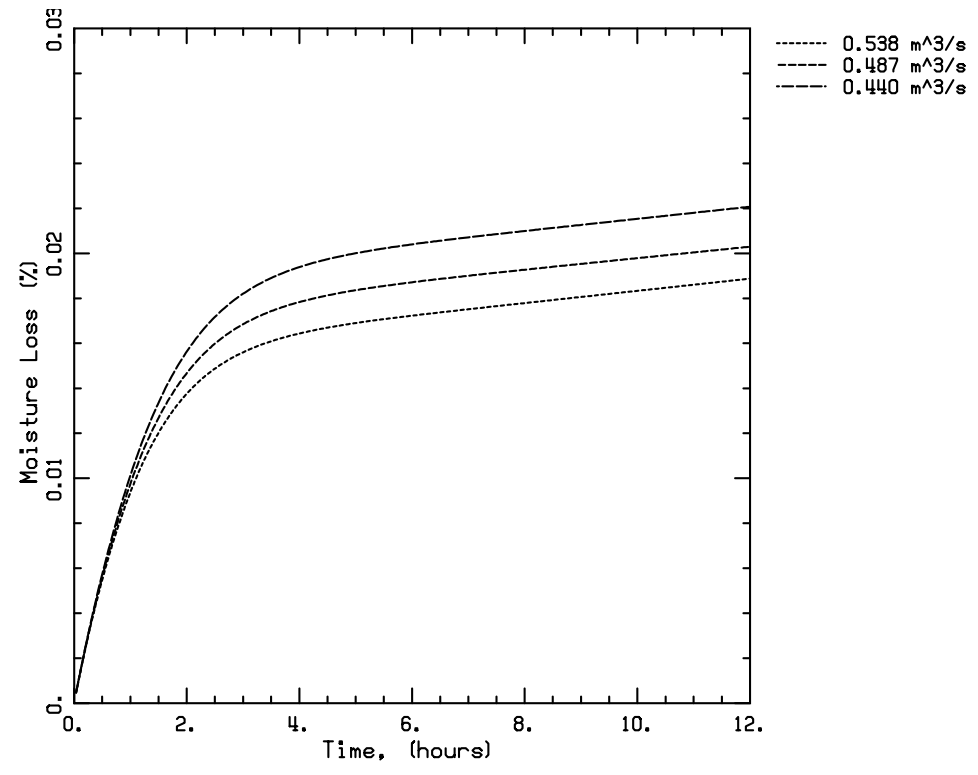

Figure 12. Effect of air flow rate on moisture loss. The approaching air temperature and humidity were $1.67^{\circ} \mathrm{C}$ and $89 \%$, respectively. 


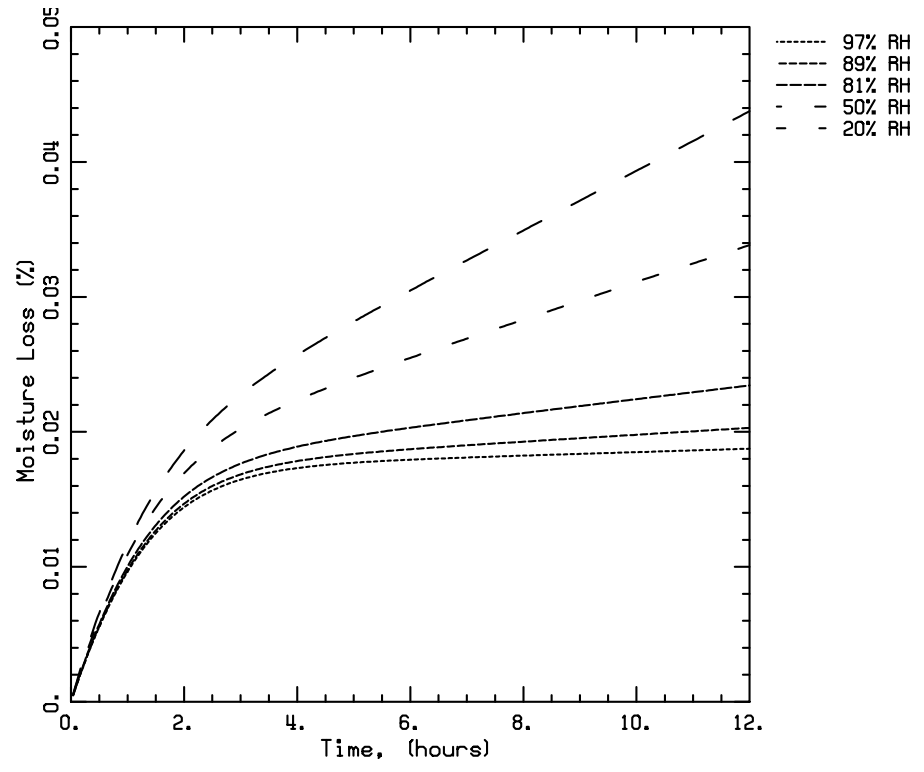

Figure 13. Effect of relative humidity on moisture loss. The approaching air temperature and flow rate were $1.67{ }^{\circ} \mathrm{C}$ and $0.487 \mathrm{~m}^{3} / \mathrm{s}$, respectively.

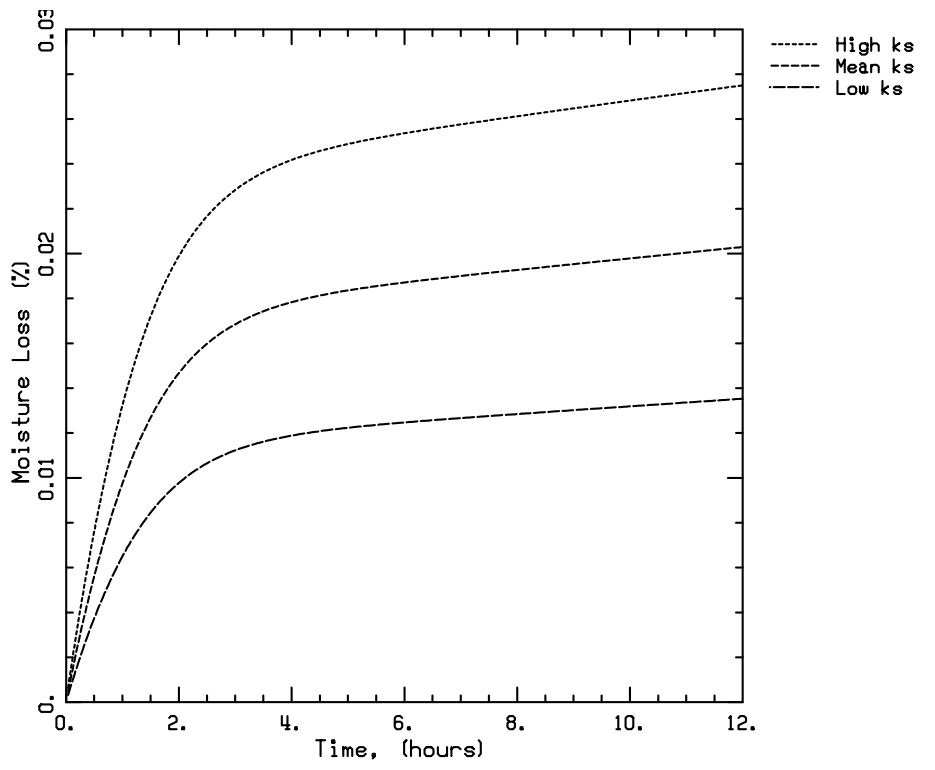

Figure 14. Effect of skin mass transfer coefficient on moisture loss. The approaching air temperature, humidity and flow rate were $1.67^{\circ} \mathrm{C}$, $89 \%$, and $0.487 \mathrm{~m}^{3} / \mathrm{s}$, respectively. 